\title{
GAMBARAN TINGKAT DEPRESI PADA LANSIA DI MASA PANDEMIC COVID-19
}

\author{
Sri Hartutik ${ }^{1}$, Anjar Nurrohmah ${ }^{2}$ \\ Fakultas Ilmu Kesehatan, Universitas Aisyiyah Surakarta ${ }^{1}$ \\ Fakultas Ilmu Kesehatan, Universitas Aisyiyah Surakarta ${ }^{2}$ \\ Srihartutik519@gmail.com
}

\begin{abstract}
Abstrak
Pandemi Covid -19 merupakan bentuk kasus baru di dunia kesehatan yang mempunyai beragam dampak, baik biologis, psikologis, sosial dan spiritual. Kondisi seperti ini harus benar-benar diwaspadai terutama pada usia rentan dan resiko yaitu salah satunya usia lansia. Depresi pada lansia merupakan gangguan psikiatri dan merupakan masalah kesehatan mental yang sering terjadi dikalangan lanjut usia. Prevalensi depresi didunia sekitar 8-15\%. Hasil survey dari berbagai negara di dunia diperoleh prevalensi rata- rata depresi pada lansia adalah 13,5 \% dengan perbandingan wanita:pria 14,1: 8,6 dimana wanita dua kali lebih banyak daripada pria. Penelitian ini bertujuan untuk Mengetahui gambaran tingkat depresi pada lansia di Masa Pandemic Covid-19. Jenis penelitian ini adalah penelitian desain deskriptif cross sectional dengan teknik consecutive sampling yang bertujuan untuk melihat gambaran tingkat depresi lansia menggunakan instrument penelitian berupa kuesioner Geriatric Depression Scale Short Form (GDS-S). Berdasarkan penelitian didapatkan hasil Umur lansia yang mengalami depresi pada masa Pandemic Covid-19 sebagian besar adalah Usia lanjut (60-74 tahun), jenis kelamin perempuan, status perkawinan lansia sebagian besar janda, riwayat penyakit lansia sebagian besar hipertensi, tingkat pendidikan lansia sebagian besar SD. Kesimpulan penelitian gambaran tingkat depresi pada lansia pada masa pandemic covid-19 sebagian besar mengalami depresi ringan.
\end{abstract}

Kata Kunci : Lansia, Depresi, Covid-19

\begin{abstract}
The Covid -19 pandemic is a form of new cases in the world of health which has various impacts, both biological, psychological, social and spiritual. Depression in the elderly is a psychiatric disorder and is a mental health problem that often occurs among the elderly. The prevalence of depression in the world is around $8-15 \%$. Survey results from various countries in the world show that the average prevalence of depression in the elderly is $13.5 \%$ with the ratio of women: men is 14.1: 8,6 where women are twice as many as men. This research aimed to determine the level of depression in the elderly during the Covid-19 Pandemic. This methode of research used a cross sectional descriptive design with consecutive sampling technique which aims to describe the level of depression in the elderly using a research instrument in the form of a Geriatric Depression Scale Short Form (GDS-S) questionnaire. The result showed Depression during the Covid-19 Pandemic was mostly elderly (60 74 years), female sex, most of the elderly marital status was widowed, history of elderly disease was hypertension, education level of the elderly was elementary school. The conclusion description of the level of depression in the elderly during the Covid-19 pandemic mostly experienced mild depression.
\end{abstract}

Keywords: Elderly, Depression, Covid-19 


\section{PENDAHULUAN}

Usia lanjut merupakan suatu kejadian yang pasti akan dialami semua orang dan tidak bisa dihindari oleh siapapun bagi manusia yang dikaruniai umur panjang. Usia tua adalah periode penutup dalam rentang hidup seseorang dimana seseorang telah melalui periode terdahulu atau masa muda yang lebih menyenangkan. (Murwani A dan Priyantari nd, 2011)

Pada tahun 2025 jumlah populasi lanjut usia di dunia diperkirakan sebesar 1,2 miliar dan sebanyak 840 juta terdapat di negara berkembang. Salah satu indikator keberhasilan pembangunan yaitu semakin meningkatnya usia harapan penduduk yang akan mempengaruhi pula angka harapan hidup lansia dari tahun ke tahun. Hasil prediksi menunjukan bahwa presentase penduduk lanjut usia akan mecapai $9,77 \%$ dari total penduduk pada tahun 2010 dan menjadi 11,34 persen pada tahun 2020. Badan kesehatan dunia WHO menyatakan bahwa penduduk lansia di Indonesia pada tahun 2020 mendatang sudah mencapai angka $11,34 \%$ atau tercatat 28,8 juta orang. (Muhit, 2016).

Berdasarkan data proyeksi penduduk, diperkirakan peningkatan jumlah lansia pada tahun 2025 (33,69 juta), tahun 2030 (40,95 juta) dan tahun 2035 (48,19 juta). (Kemenkes RI, 2018). Pusat Data dan Informasi Kementrian Kesehatan RI (2016:12) berdasarkan Undang-Undang
Nomor 13 tahun 1998 tentang Kesejahteraan Lanjut Usia, lansia adalah seseorang yang mencapai usia 60 tahun ke atas. Secara global populasi lansia diprediksi terus mengalami peningkatan. Indonesia akan memasuki periode lansia (ageing), dimana $10 \%$ penduduk akan berusia 60 tahun ke atas, ditahun 2020 seperti terlihat pada gambar di bawah.

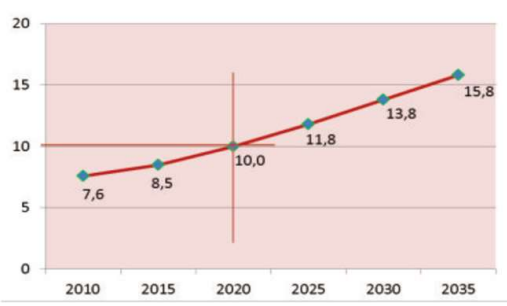

Sumber: Badan Pusat Statistik, Proyeksi Penduduk 2010-2035

Gambar 1 Persentase Penduduk Lansia di Indonesia Tahun 2010 - 2035

Depresi menyerang 10\%$15 \%$ lansia 65 tahun keatas yang tinggal dikeluarga dan angka depresi meningkat secara drastis pada lansia yang tinggal di institusi, dengan sekitar 50-75\% penghuni perawatan jangka panjang memiliki gejala depresi ringan sampai sedang. (Azizah, 2011). Depresi pada lansia merupakan gangguan psikiatri dan merupakan masalah kesehatan mental yang sering terjadi dikalangan lanjut usia. (Sari, 2012). Prevalensi depresi didunia sekitar $8-15 \%$ dan hasil survey dari berbagai negara di dunia diperoleh prevalensi rata- rata depresi pada lansia adalah 13,5 \% dengan perbandingan wanita: pria ialah 14,1: 8,6 dimana wanita dua kali lebih banyak daripada pria.

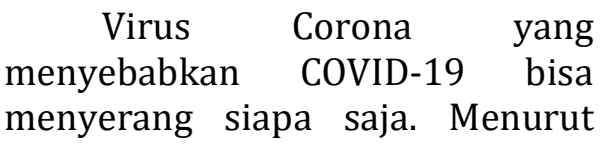


data yang dirilis Gugus Tugas Percepatan Penanganan COVID-19 Republik Indonesia, jumlah kasus terkonfirmasi positif hingga 12 Agustus 2020 adalah 130.718 orang dengan jumlah kematian 5.903 orang. Tingkat kematian (case fatality rate) akibat COVID19 adalah sekitar 4,5\%. Dilihat dari persentase angka kematian yang di bagi menurut golongan usia, maka lansia memiliki persentase tingkat kematian yang lebih tinggi dibandingkan golongan usia lainnya. Sedangkan berdasarkan jenis kelamin, $59,1 \%$ penderita yang meninggal akibat COVID-19 adalah laki-laki dan 40,9\% sisanya adalah perempuan. Tujuan penelitian ini adalah untuk mengetahui tingkat depresi lansia pada masa Pandemic covid 19.

\section{METODE}

Jenis penelitian yang digunakan adalah Deskriftif kuantitatif, Metode penelitian ini menggunakan rancangan cross sectional. Populasi dalam penelitian ini adalah semua lansia yang mengalami depresi di komunitas keluarga mahasiswa Universitas 'Aisyiyah Surakarta, dengan jumlah sampel 60 orang. Variabel Bebas pada penelitian ini adalah lansia dan variable terikatnya adalah tingkat depresi. Tehnik pengumpulan data dalam penelitian ini adalah dengan cara kuesioner atau angket yaitu dengan memberikan beberapa pertanyaan kepada responden untuk dijawab. Analisa data yang digunakan dalam penelitian ini dengan menggunakan menggunakan kuesioner Geriatric Depression Scale (GDS) sejumlah 30 pertanyaan. Kriteria inklusi dalam penelitian ini adalah Lansia yang mengalami depresi, Usia lansia $>60$ thn, bersedia menjadi responden dan tinggal di dalam Keluarga

\section{HASIL}

Penelitian ini dilakukan untuk mengetahui gambaran tingkat depresi pada lansia di Masa Pandemic Covid-19 dengan hasil sebagai berikut :

\section{Distribusi karakteristik responden (umur, jenis kelamin \& status perkawinan) lansia yang mengalami depresi pada masa Pandemic Covid-19}

Tabel 1 Distribusi frekuensi umur, jenis kelamin \& status perkawinan lansia yang mengalami depresi pada masa pandemic covid-19 


\begin{tabular}{|c|c|c|c|c|}
\hline \multirow{2}{*}{ No } & \multirow{2}{*}{$\begin{array}{l}\text { Karakt } \\
\text { eristik }\end{array}$} & \multirow{2}{*}{$\begin{array}{c}\text { Klasifi } \\
\text { kasi }\end{array}$} & \multicolumn{2}{|c|}{ Jumlah } \\
\hline & & & $\mathrm{F}$ & $\%$ \\
\hline \multicolumn{5}{|c|}{ Umur } \\
\hline 1 & $\begin{array}{c}60-74 \\
\text { th }\end{array}$ & $\begin{array}{l}\text { Usia } \\
\text { lanjut }\end{array}$ & 50 & 83 \\
\hline 2 & $\begin{array}{c}75-89 \\
\text { th }\end{array}$ & $\begin{array}{c}\text { Usia } \\
\text { tua } \\
\text { Usia }\end{array}$ & 8 & 13 \\
\hline 3 & $>90$ th & $\begin{array}{c}\text { sangat } \\
\text { lanjut }\end{array}$ & 2 & 4 \\
\hline \multicolumn{5}{|c|}{ Jenis Kelamin } \\
\hline 4 & $\begin{array}{c}\text { Laki- } \\
\text { laki }\end{array}$ & & 18 & 30 \\
\hline 5 & $\begin{array}{c}\text { Perem } \\
\text { puan }\end{array}$ & & 42 & 70 \\
\hline \multicolumn{5}{|c|}{ Status perkawinan } \\
\hline 6 & Janda & & 30 & 50 \\
\hline 7 & Duda & & 18 & 30 \\
\hline 8 & $\begin{array}{c}\text { Menik } \\
\text { ah }\end{array}$ & & 12 & 20 \\
\hline 9 & $\begin{array}{l}\text { Tidak } \\
\text { menik } \\
\text { ah }\end{array}$ & & 0 & 0 \\
\hline & Total & & 60 & 100 \\
\hline
\end{tabular}

\section{Distribusi Riwayat penyakit lansia yang mengalami depresi}

\begin{tabular}{clcc}
\hline \multirow{2}{*}{ No } & Penyakit Penyerta & Jumlah \\
& & $\mathrm{F}$ & $\%$ \\
\hline 1 & Hipertensi & 21 & 35 \\
2 & Artritis Gout & 16 & 27 \\
3 & Diabetes Melitus & 3 & 5 \\
4 & Osteoporosis & 3 & 5 \\
5 & Stroke & 2 & 4 \\
6 & Gastritis & 1 & 2 \\
7 & Tidak ada penyakit & 14 & 22 \\
\hline & Total & 60 & 100 \\
\hline
\end{tabular}

pada masa Pandemic Covid-19

Tabel 2 Distribusi frekuensi Riwayat penyakit lansia yang mengalami depresi pada masa pandemic covid-19

Berdasarkan tabel 2 menunjukkan bahwa riwayat penyakit alansia sebagian besar adalah Hipertensi dengan jumlah 21 orang (35\%), Artritis Gout 16 orang (27\%), Diabetes mellitus 3

Berdasarkan tabel 1 menunjukkan bahwa umur lansia sebagian besar adalah Usia lanjut (60 thn-74 thn) dengan jumlah 50 orang (83\%), Usia tua dengan jumlah 8 orang (13\%) dan Usia sangat lanjut dengan jumlah 2 orang (4\%). Jenis kelamin lansia sebagian besar adalah perempuan dengan jumlah 42 orang (70\%),

\begin{tabular}{|c|c|c|c|}
\hline \multirow[b]{2}{*}{ No } & \multirow[t]{2}{*}{ Pendidikan } & \multicolumn{2}{|c|}{ Jumlah } \\
\hline & & $\mathrm{F}$ & $\%$ \\
\hline 1 & SD & 36 & 60 \\
\hline 2 & SMP & 4 & 7 \\
\hline 3 & SLTA & 2 & 3 \\
\hline 4 & Tidak sekolah & 18 & 30 \\
\hline & Total & 60 & 100 \\
\hline
\end{tabular}

\%). Status perkawinan lansia sebagian besar adalah janda dengan jumlah 30 orang (50\%), Duda dengan jumlah 18 orang (30\%) dan Menikah dengan jumlah 12 orang (12\%) orang (5\%), Osteoporosis 3 orang (5 \%), Stroke 2 orang (4 \%), Gastritis 1 orang (2\%) dan tidak ada penyakit sejumlah 14 orang (22\%).

\section{Distribusi Tingkat pendidikan lansia yang megalami depresi pada masa pademic Covid-19}

Tabel 3 Distribusi frekuensi tingkat pendidikan lansia yang mengalami depresi pada masa pandemic covid-19

Berdasarkan tabel 3 menunjukkan bahwa tingkat Pendidikan lansia sebagian besar adalah SD dengan jumlah 36 orang (60\%), SMP sejumlah 4 orang (7\%), SLTA 2 orang $(3 \%)$ dan tidak sekolah 18 orang (30\%). 
4. Gambaran tingkat depresi pada lansia pada masa pandemic covid-19

Tabel 4 Distribusi frekuensi gambaran tingkat depresi pada lansia pada masa pandemic covid-19

\begin{tabular}{clcc}
\hline & Tingkat Depresi & \multicolumn{2}{c}{ Jumlah } \\
No & & F & $\%$ \\
\hline 1 & Depresi Ringan & 31 & 52 \\
2 & Depresi sedang & 29 & 48 \\
3 & Depresi berat & 0 & 0 \\
& & & \\
\hline & Total & 60 & 100 \\
\hline
\end{tabular}

Berdasarkan tabel 4 menunjukkan bahwa lansia yang mengalami depresi pada masa pandemic covid-19 sebanyak 31 orang (52 $\%$ ) mengalami depresi ringan dan lansia yang mengalami depresi sedang sebanyak 29 orang (48\%).

\section{PEMBAHASAN}

\section{Karakteristik responden (umur, jenis kelamin \& status perkawinan) lansia yang mengalami depresi pada masa Pandemic Covid-19}

Hasil penelitian menunjukkan bahwa umur lansia sebagian besar adalah Usia lanjut (60 thn-74 thn) dengan jumlah 50 orang (83\%), Usia tua dengan jumlah 8 orang (13\%) dan Usia sangat lanjut dengan jumlah 2 orang (4\%). Hal ini sejalan dengan penelitian Putri 2016 yang menyebutkan bahwa mayoritas responden $(75,5 \%)$ berada pada kategori lanjut usia (60-74 tahun). Hal ini juga sejalan dengan hasil penelitian Darmawan, 2016 yang menyebutkan bahwa umur paling banyak pada rentang 60-74 tahun sebesar $49.1 \%$. Menurut penelitian Novayanti, 2020 menunjukkan bahwa mayoritas lansia yang tinggal di Panti Sosial berada pada rentang usia 65-69 tahun yaitu sebanyak 50 lansia (37,0\%). Temuan ini sesuai dengan hasil penelitian menunjukkan bahwa prevalensi depresi meningkat sejalan dengan bertambahnya usia lansia. (Lindia Prabhaswari, 2015). Seiring bertambahnya usia, maka akan terjadi peningkatan morbiditas, penurunan status fungsional, serta adanya paparan berbagai faktor risiko dan pengalaman hidup yang dapat mempengaruhi kejiwaan lansia, sehingga berisiko menempatkan lansia dalam keadaan depresi. (Kartika, 2012).

Lansia merupakan tahap lanjut dari kehidupan dimana terjadi penurunan kemampuan tubuh dalam melakukan adaptasi terhadap stress lingkungan. Perubahan fungsi fisik, perubahan fungsi kognitif, dan perubahan psikososial merupakan perubahan yang terjadi pada proses penuaan yang dapat membuat timbulnya depresi pada lansia.(Kurniawan, 2016)

Hasil penelitian menunjukkan bahwa Jenis kelamin lansia yang mengalami depresi sebagian besar adalah perempuan dengan jumlah 42 orang $(70 \%)$, dan Laki-laki 18 orang (30\%). Menurut penelitian Kurniawan, et all depresi lebih sering terjadi pada wanita. Depresi merupakan endapan dari perasaan cemas yang dapat dipengaruhi oleh perubahan hormon. Adanya depresi pada wanita berkaitan dengan ketidakseimbangan hormon pada wanita menambah 
tingginya prevalensi depresi. Ketidakseimbangan hormon dapat terjadi pada wanita yang mengalami menopause atau pasca melahirkan. Menopouse yang terjadi dapat memengaruhi keadaan psikologis pada wanita seperti mudah tersinggung, cepat marah, merasa tertekan, merasa tidak berguna, mudah lupa, dan dapat mengalami depresi ringan pada masa perubahan hormonal.

$$
\text { Pada wanita usia lanjut, }
$$
depresi juga terkait dengan meningkatnya sensitivitas perasaan sehingga lebih mudah merasa tersinggung di samping merasa lebih rentan terhadap masalah yang dihadapi. (Kurniawan, 2016). Penelitian oleh Agus yang menyatakan bahwa jenis kelamin perempuan merupakan faktor yang berpengaruh terhadap tingkat depresi pada lansia.

Hasil penelitian Agus Bhayu, 2014 mengemukakan bahwa berdasarkan karakteristik jenis kelamin, menunjukkan bahwa proporsi kejadian depresi lebih banyak terjadi pada jenis kelamin perempuan dibandingkan laki-laki. Menurut beberapa studi lansia perempuan memang memiliki risiko depresi lebih tinggi dibandingkan dengan lansia lakilaki dengan perbandingan antara perempuan dan laki-laki yaitu 2:1. Selain itu hasil yang serupa juga didapatkan pada penelitian yang dilakukan oleh Leal et all 2014 yang melakukan penelitian prevalensi pada lansia di Portugal dan Brazil mendapatkan hasil bahwa proporsi terjadinya depresi pada lansia lebih banyak pada perempuan dengan proporsi $81,0 \%$ pada lansia perempuan di
Brazil dan $62,4 \%$ pada lasia perempuan di Portugal.15.

Penelitian yang dilakukan oleh Das et all 2014, menunjukkan bahwa berdasarkan jenis kelamin kejadian depresi terbanyak terjadi pada perempuan. Hasil yang berbeda justru didapatkan pada penelitian Onya \& Nailil , 2013 yang menyatakan bahwa proporsi terjadinya depresi lebih banyak pada perempuan, Hal ini dapat disebabkan karena adanya beberapa faktor lain yang kemungkinan mempengaruhi depresi, seperti: kematian pasangan hidup, perbedaan sosial dan budaya, dan kurangnya partisipasi dalam beraktivitas selama masa hidupnya.

Proporsi depresi yang lebih banyak terjadi pada perempuan daripada laki-laki kemungkinan juga diakibatkan oleh adanya pengaruh perubahan fisiologis, misalnya early onset of menopauseatau post-menopause. Karena pada penelitian ini usia sampel dimulai pada usia 60 tahun ke atas, kemungkinan pada masa ini sampel perempuan pada penelitian ini berada dalam tahap postmenopause. Sehingga sesuai dengan kemungkinan faktor risiko yang dapat menyebabkan depresi lebih banyak pada perempuan dibandingkan laki-laki. Hasil yang cukup berbeda justru ditemukan pada penelitian yang dilakukan oleh Kartika (2012), hasil yang didapatkan bahwa proporsi kejadian tertinggi depresi terdapat pada lansia laki-laki. Perbedaan tersebut kemungkinan disebabkan karena lokasi penelitian yang berbeda, pada penelitian ini berlokasi di komunitas sehingga sedikit sulit untuk mendeteksi 
depresi pada laki-laki dan memang kebanyakan yang datang ke pusat pelayanan kesehatan untuk keluhan depresi adalah perempuan.

$\begin{array}{cr}\text { Hasil } & \text { penelitian } \\ \text { menunjukkan } & \text { bahwa }\end{array}$ perkawinan lansia sebagian besar adalah Janda dengan jumlah 30 orang (50\%), Status duda dengan jumlah 18 orang (30\%) dan status masih menikah sejumlah 12 orang (20 \%). Menurut penelitian Sari 2012, mengemukakan bahwa seseorang yang berstatus duda/janda atau tidak menikah berisiko hidup sendiri, dimana hidup sendiri juga merupakan faktor risiko terjadinya depresi pada lansia. Lansia yang memiliki pasangan hidup akan memiliki tempat untuk saling berbagi dan mendukung dalam menghadapi masa tua sehingga risiko terkena depresi lebih rendah. (Kartika, 2012).

Lansia memiliki pasangan hidup dapat mengalami depresi. Depresi lebih sering terjadi pada lansia yang masih menikah daripada lansia yang tidak menikah misalnya berstatus janda, duda atau belum menikah. (Marta,2012). Hal tersebut dapat terjadi karena berdasarkan teori interpersonal oleh Davinson, 2006 menyatakan bahwa perpecahan keluarga dan interaksi antara orang yang depresi dengan pasangan hidup sering terjadi.pada lansia yang hidup sendiri mengalami depresi yang lebih rendah karena dapat mengurangi frekuensi marah. Penelitian Wahyuni, 2011 menjelaskan bahwa lansia yang masih mempunyai pasangan hidup mempunyai tingkat kecemasan lebih rendah dari pada lansia yang sudah tidak mempunyai pasangan hidup di Wilayah Puskesmas Gemolong II.

Penelitian Saraswati, 2019 menyebutkan bahwa Lansia yang menderita depresi ringan ditemukan pada lansia yang menikah (termasuk di dalamnya janda dan duda). Menurut literatur, studi epidemiologi di antara orang yang menikah dan tidak menikah menunjukkan bahwa angka depresi lebih tinggi di antara mereka yang tidak pernah menikah atau sebelumnya pernah menikah dibandingkan dengan yang masih mempunyai pasangan menikah. Penelitian depresi pada lansia di Karangasem, Bali melaporkan bahwa persentase depresi lebih tinggi pada lansia yang tidak menikah (57,3\%) dibandingkan dengan yang menikah (25,9\%). Penelitian di daerah urban India menunjukkan skor depresi yang sangat tinggi pada lansia yang tidak menikah. Penelitian di Alexandria, Mesir yakni persentase depresi lebih tinggi pada lansia yang tidak menikah (80\%), ditinggal mati pasangan $(90 \%)$, atau bercerai (75\%) dibandingkan dengan lansia yang menikah $(31,7 \%)$.

\section{Riwayat penyakit lansia yang mengalami depresi pada masa Pandemic Covid-19}

Hasil penelitian menunjukkan bahwa riwayat penyakit lansia sebagian besar adalah Hipertensi dengan jumlah 21 orang (35\%), Artritis Gout 16 orang (27\%), Diabetes mellitus 3 orang (5\%), Osteoporosis 3 orang (5 \%), Stroke 2 orang (4\%), Gastritis 1 orang (2 
\%) dan tidak ada penyakit sejumlah 14 orang (22 \%). Dalam penelitian Saraswati et all 2019 mengemukakan bahwa Lansia dengan depresi ringan ditemukan pada kelompok lansia yang menderita penyakit kronis sebanyak $12,5 \%$ dan pada lansia yang tidak menderita penyakit kronis sebanyak 4,5\%. Literatur menyatakan bahwa penyakit medis yang serius merupakan faktor risiko depresi yang diketahui secara umum. Hal ini sesuai dengan hasil penelitian depresi pada lansia di Karangasem, Bali yang menyatakan bahwa persentase depresi lebih tinggi ditemukan pada lansia yang menderita penyakit kronis (74,2\%) dibandingkan dengan yang tidak $(21,8 \%)$, dan hubungannya sangat signifikan. Hal yang serupa juga ditemukan pada penelitian di Alexandria, Mesir dimana persentase depresi pada lansia yang menderita penyakit kronis adalah $54,1 \%$ dan yang tidak adalah $0 \%$.

Menurut Baert, et al., 2011, kondisi fisik merupakan kunci dalam melakukan aktivitas fisik pada lansia. Lansia yang sehat mampu menjalankan aktivitas senam secara aktif dan rutin. Hal ini didukung oleh penelitian Giulli, et al., 2012 yang menyatakan bahwa lansia yang menganggap dirinya sehat akan lebih aktif melakukan aktivitas fisik. Penelitian Rasinaho, et al., 2006 mengungkapkan lansia yang memiliki keluhan penyakit memiliki dorongan motivasi untuk melakukan aktivitas fisik seperti persepsi keuntungan terhadap kesehatan, pengalaman positif dan menyenangkan, serta lingkungan yang menyenangkan.

Lansia yang memiliki penyakit kronik selama bertahuntahun pada umumnya akan menjadikan lansia lebih mudah untuk terkena depresi. Penelitian Kurniawan, 2016 mengemukakan bahwa Prevalensi tertinggi terjadi pada lansia dengan riwayat penyakit jantung yaitu salah satunya sindrom koroner akut. Depresi juga merupakan salah satu faktor yang signifikan dalam meningkatkan morbiditas dan mortalitas penyakit jantung. Gejala depresi yang timbul seringkali tidak diketahui oleh lansia sehingga tidak ada terapi yang diberikan yang menyebabkan gejala depresi tersebut menetap selama berbulan bulan.

Hubungan antara penyakit somatik dan medikasi dengan depresi pada lansia akan semakin nampak seiring dengan pertambahan umur yang terjadi. Depresi dapat menjadi manifestasi langsung dari penyakit somatik atau efek dari pengobatan, reaksi dari diagnosis penyakit kronis, atau dapat terjadi bersamaan dengan keluhan fisik. Depresi dapat terjadi pada lansia dengan penyakit stroke atau penyakit kardiovaskular, dan penurunna kemampuan fungsional tubuh lainnya.

\section{Tingkat pendidikan lansia yang megalami depresi pada masa pademic Covid-19}

Hasil penelitian menunjukkan bahwa tingkat Pendidikan lansia sebagian besar adalah SD dengan jumlah 36 orang (60\%), SMP 
sejumlah 4 orang (7\%), SLTA 2 orang $(3 \%)$ dan tidak sekolah 18 orang (30 \%). Penelitian Saraswati, 2019 mengemukakan bahwa Lansia dengan depresi ringan ditemukan pada kelompok lansia yang pendidikan terakhirnya SD sebanyak 33,3\% dan pada lansia yang pendidikan terakhirnya lebih tinggi dari SMA sebanyak 6,7\%.

Penelitian lain di Alexandria, Mesir dimana ditemukan persentase depresi yang lebih tinggi pada kelompok lansia yang tidak bersekolah $(66,7 \%)$ dan yang bersekolah sampai sekolah dasar (61,5\%) dibandingkan dengan lansia yang bersekolah sampai sekolah menengah atau universitas (24,5\%).7 Penelitian di Karangasem, Bali mendapatkan hasil dimana lansia yang tidak bersekolah $(59,6 \%)$ memiliki persentase depresi yang lebih tinggi dibandingkan dengan lansia yang bersekolah $(17,4 \%)$ dan terdapat hubungan yang signifikan antara tingkat depresi dan tingkat pendidikan.

Penelitian Kurniawan et all 2016 mengemukakan bahwa Tingkat pendidikan merupakan salah satu hal terpenting dalam menghadapi masalah. Semakin tinggi Pendidikan seseorang, semakin banyak pengalaman hidup yang dihadapi, sehingga akan lebih siap dalam menghadapi masalah yang terjadi. Pada umumnya lansia yang memiliki tingkat pendidikan yang tinggi masih dapat produktif, sehingga akan banyak memberikan kontribusi seperti menulis bukubuku ilmiah maupun biografinya sendiri.

Tingkat pendidikan akan sangat berpengaruh terhadap kejadian depresi dikarenakan tingkat pendidikan lansia baik dari SD, SMP, SMA, hingga perguruan tinggi akan mempengaruhi kemampuan lansia dalam mengambil keputusan.Kondisi ini terkadang menjadi penyebab terjadinya depresi dipengaruhi adanya pengetahuan dan ekonomi dari lansia.

Pendidikan dapat mempengaruhi perilaku seseorang. Semakin tinggi pendidikan seseorang, maka akan semakin mudah menerima informasi sehingga semakin banyak pula pengetahuan yang dimiliki. disamping itu, pendidikan juga merupakan modal awal dalam perkembangan kognitif, dimana kognitif tersebut dapat menjadi mediator antara suatu kejadian dan mood, sehingga kurangnya pendidikan dapat menjadi faktor risiko lansia menderita depresi.(Livana PH \& Yulia S, 2019)

\section{Gambaran tingkat depresi pada lansia pada masa pandemic covid-19}

Hasil penelitian menunjukkan bahwa lansia yang mengalami depresi pada masa pandemic covid-19 sebanyak 31 orang (52 \%) mengalami depresi ringan dan lansia yang mengalami depresi sedang sebanyak 29 orang (48 \%). Penelitian Lindia Prabhaswari, $\quad 2015$ mengungkapkan bahwa beragam faktor yang dapat menyebabkan kenaikan tingkat depresi lansia, diantaranya dukungan keluarga dan tempat tinggal. Salah satu faktor yang paling utama untuk mendasari terjadinya depresi, 
karena kehilangan merupakan suatu keadaan individu yang berpisah dengan suatu yang sebelumnya ada. Lansia yang tidak memiliki keluarga untuk menemani lansia dapat mengurangi kontribusi lansia dalam melakukan aktivitas sehingga rasa jenuh dan sepi yang dirasakan oleh lansia meningkat (Nailil, \& Arwani, 2013).

Lansia yang baru menetap di panti cenderung membutuhkan adaptasi di tahun awal kehidupan di panti sehingga kurang interaksi antar lansia. Kehilangan keluarga atau orang yang disayangi merupakan pencetus timbulnya depresi. Responden merasa disakiti, diacuhkan oleh keluarga, dibuang oleh keluarga dan kurangnya perhatian dari keluarga (Maslim, 2013). Seyogyanya masa tua yang dirasakan lansia seharusnya merasakan kasih sayang ditengah keluarga serta menikmati hasil jerih payah yang sepanjang hidupnya telah dicapai. Namun, kenyataan yang dihadapi lansia justru sebaliknya (Johana., 2014). Rasa sepi yang secara terus menerus dirasakan oleh lansia mengakibatkan beberapa dampak bagi kesehatan lansia baik secara fisik maupun psikologis. Keadaan tidak tertanganinya masalah kesepian pada lansia dapat memperparah tingkat depresi dan mengganggu kualitas hidup lansia itu sendiri. Hal tersebut diatas dibuktikan oleh penelitian bahwa lansia yang mengalami depresi sangat rentan terhadap masalah lain seperti peningkatan tekanan darah.

\section{SIMPULAN}

Pada Penelitian ini dapat disimpulkan sebagai berikut :

1. Distribusi Karakteristik responden lansia (Umur lansia yang mengalami depresi pada masa Pandemic Covid-19 sebagian besar adalah Usia lanjut. Jenis kelamin lansia yang mngalami depresi pada masa pandemic Covid-19 sebagian besar adalah perempuan. Status perkawinan lansia yang mengalami depresi pada masa pandemic Covid-19 sebagian besar adalah Janda.

2. Riwayat penyakit lansia yang mengalami depresi pada masa Pandemic Covid-19 sebagian besar adalah Hipertensi.

3. Tingkat pendidikan lansia yang megalami depresi pada masa pademic Covid-19 sebagian besar adalah SD.

4. Gambaran tingkat depresi pada lansia pada masa pandemic covid-19 sebagian besar mengalami depresi ringan.

\section{REFERENSI}

Azizah, L. 2011. Keperawatan Lanjut Usia. Graha Ilmu. Yogyakarta.

Baert, V.B., Gorus, E., Mets, T., Geerts, C., \& Bautmans, I. (2011). Motivators and barriers for physical activity in the oldest old: A systematic review. Journal of Ageing Research, 10, 464467. doi: 10.1016/j.arr.2011 .04 .001

Bhayu, A. Ratep Nyoman. Westa Wayan. 2014. Gambaran Faktor-Faktor Yang Mempengaruhi Tingkat 
Depresi Pada Lanjut Usia Di Wilayah Kerja Puskesmas Kubu Ii Januari-Februari 2014. Program Studi Pendidikan Dokter Fakultas Kedokteran Universitas Udayana, Bali. 2014

Das J, Farzana FD, Ferdous F, Ahmed S, dkk. Factors associated with elderly depression among rural Bangladeshi individuals. American Journal of Psychiatry and Neuroscience. 2014; 2(1): 1-7.

Darmawan, D. 2016. Gambaran Tingkat Depresi Pada Lansia Yang Tinggal Di Panti Griya Sehat Bahagia Palur Karanganyar. Skripsi. Universitas Muhammadiyah Surakarta

Giuli, C., Papa, R., Mocchegiani, E., \& Marcellini, F. (2012). Predictors of participation in physical activity for community-dwelling elderly Italians. Journal Gerontology Geriatric, 54 (1), 50-54. doi: http://dx.doi.org/ 10.1016/j.archger.2011.02.0 17

Johana. (2014) 'Aspek SosioPsikologis Usia Lanjut Di Indonesia. Buletin Penelitian Kesehatan', Fakultas Psikologi Universitas Gajah Mada, No. 21 (4).

Kartika S. Gambaran tingkat depresi pada lanjut usia (lansia) di panti sosial tresna wredha budi mulia 01 dan 03 jakarta timur [skripsi]. Universitas Indonesia. 2012:1-74.
Kementrian Kesehatan RI (2016:12). Undang-Undang Nomor 13 tahun 1998 tentang Kesejahteraan Lanjut Usia

Kemenkes RI (2018) 'Hasil Utama Riskesdas 2018', Kemenkes RI: Badan Penelitian dan Pengembangan Kesehatan.

Kurniawan Angga. 2016. FaktorFaktor Yang Memengaruhi Tingkat Depresi Pada Lanjut Usia Di Panti Graha Werdha Marie Yoseph Pontianak. Skripsi. Universitas Tanjungpura Pontianak.

Leal MCC, Apostolo JLA, Mendes AMOC, Marques APO. Prevalence of depressive symptoms and associated factors among institutionalized elderly. Acta Paul Enferm. 2014; 27(3): 208-214.

Lindia Prabhaswari, N. L. P. A. (2015) 'Gambaran kejadian depresi pada lanjut usia di wilayah kerja Puskesmas Petang I Kabupaten Badung Bali', Program Studi Pendidikan Dokter, Fakultas Kedokteran Universitas Udayana, 7 No. 1(ISSN: 20899084

Livana, P. H., Susanti, Y., Darwati, L. E., \& Anggraeni, R. (2018). Gambaran Tingkat Depresi Lansia. Nurscope. Jurnal Keperawatan Pemikiran Ilmiah, 4(4), 8093. http://jurnal.unissula.ac.id/ index.php/jnm/ar ticle/view/3936 
Marta, O. F. (2012). Determinan tingkat depresi pada lansia di panti sosial tresna werdha Budi Mulia 4 Jakarta Selatan (Skripsi, Universitas Indonesia). Universitas Indonesia, Jakarta.

Maslim, R. (2013) Buku Saku Diagnosisi Gangguan Jiwa Rujukan Ringks dari PPDGJIII dan DSM-5. Jakarta.: Ilmu Kedokteran Jiwa FK Unika Atmaja

Muhith, A., dan Siyoto, S. 2016. Pendidikan Keperawatan Gerontik. Andi. Yogyakarta.

Murwani, A., dan Priyantari, W. 2011. Gerontik : Konsep Dasar dan Asuhan Keperawatan Home Care dan Komunitas. Fitramaya. Yogyakarta.

Muhit, A. Sriyoto. 2016. DasarDasar Keperawatan Jiwa: Pengantar dan Teori. Salemba Medika. Jakarta.

Nailil, Arwani, \& P. (2013) 'Hubungan antara karakteristik dengan kejadian depresi pada lansia di panti werda pelkris pengayoman [Semarang]', Stikes Telogorejo, Vol 2, pp. 1-9.

Onya ON, Stanley PC. Risk factors for depressive illness among elderly gopd attendees at upth. IOSR Journal of Dental and Medical Sciences. 2013; 5(2): 77-86

Pusat Data dan Informasi Kementrian Kesehatan RI (Pusdatin). 2016. Situasi
Lanjut Usia (Lansia) di Indonesia. www.pusdatin.kemenkes.go .id. Diakses tanggal 5 Mei 2020 (15.00).

Novayanti Eka Putu. Adi Sakundoro Mateus. Widyastuti Hadi Rita. 2020. Tingkat Depresi Lansia Yang Tinggal Di Panti Sosial. Jurnal Keperawatan Jiwa 8 (2) : 117 - 122, Mei 2020

Putri Irsa Sartika. Fitriyani Poppy. Gambaran Tingkat Depresi Lansia Yang Melakukan Senam Di Panti Sosial Tresna Werdha Di Jakarta. Jurnal Keperawatan Indonesia.19 (2) : 92-99. Juli 2016

Rasinaho, M. (2006). Motives for and barriers to phyiscal activity among older adults with mobility limitation. Journal of Aging and Physical Activity, 15 (1), 90-102. Diperoleh dari https://www.ncbi.nlm.nih.go v/pubmed/17 387231

Saraswati Cahayani Ade. Wahyuni Sri Ayu. 2019. Gambaran Depresi Pada Orang Lanjut Usia Di Perhimpunan Werdha Sejahtera (Pws) Kota Denpasar. Jurnal Medika Udayana. 8 (9)

Sari, K. (2012). Gambaran tingkat depresi pada lanjut usia di Panti Sosial Tresna Werdha Budi Mulya 01 dan 03 Jakarta Timur. (Skripsi sarjana, Universitas Indonesia). Universitas Indonesia, Jakart

Virus

Corona. https://www.alodokter.com/vir 
Wahyuni, T. (2011) Analisis Faktor yang Berhubungan dengan Kecemasan pada Lanjut Usia yang Memiliki Pasangan Hidup di wilayah PUSKESMAS Gemolong II. Naskah publikasi, tidak diterbitkan. Fakultas Ilmu Kesehatan Universitas Muhammadiyah Surakarta. 